\title{
27. PALYNOLOGY OF THE LATE TERTIARY SEQUENCE AT SITE 365, LEG 40, DEEP SEA DRILLING PROJECT
}

\author{
Alan D. Partridge, Esso, Australia Ltd.
}

\begin{abstract}
Palynological examination of cores from Site 365 situated in the Angola Basin off the west coast of Africa give a late Tertiary age for Cores 4 to 7 but a Late Cretaceous age for the shallower Core 3 .

In an attempt to reach the salt at the base of the Cretaceous sequence in the Angola Basin, Site 365 was located over a submarine canyon to take advantage of a thinner Cretaceous section. The abandonment of the hole while still in Tertiary sediments as indicated by Core 7 suggests that the younger sediments filling the canyon were not entirely penetrated.The Late Cretaceous fossils from Core 3 can be interpreted to indicate the presence within the canyon fill of either slumped or faulted blocks from the canyon walls.
\end{abstract}

\section{INTRODUCTION}

Six samples from Cores 3 to 7 from Site 365 in the Angola Basin (Figure 1), off the west coast of Africa, were analyzed by palynology to date the sequence penetrated. The initial paleontological examination of the cores onboard Glomar Challenger found only arenaceous foraminifers; their occurrence plus a depth correlation with the adjacent Site 364 were used to derive a Cretaceous age for the sequence (Bolli, Ryan, et al., 1975).

Site 365 was located over a submarine canyon. The palynological determination of a late Tertiary age for Cores 4 to 7 (overlain by sediments with an anomalous Late Cretaceous age in Core 3 ), suggests that the hole did not penetrate the canyon fill. Time constraints caused the hole to be abandoned after retrieving Core 7. The Late Cretaceous sample from Core 3 did not contain any species common with the Tertiary assemblages from the underlying cores and was in composition and preservation similar to assemblages from Site 364 (Chapter 4, this volume). The Cretaceous age is therefore thought to represent a slumped or faulted block within Site 365 and not to reflect reworking of older sediments.

\section{LATE TERTIARY ASSEMBLAGES}

The spore-pollen and dinoflagellate assemblages from the five samples examined from Cores 4 to 7 are interpreted to have a general late Neogene age range. On the basis of documented stratigraphic ranges, the age can be further restricted to late Miocene. However, the author has reservations in specifying a more exact age than late Neogene because of uncertainties of stratigraphic ranges, especially points of extinction, of many of the species identified.

All the samples contain diverse assemblages. The species identified and their distributions are given in

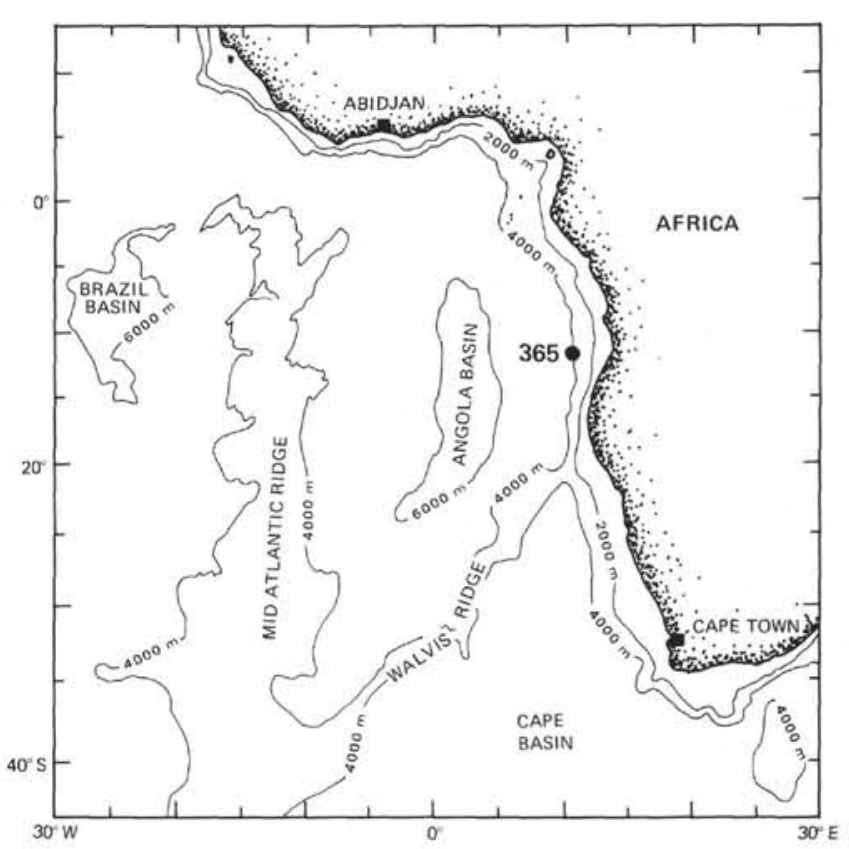

Figure 1. Location of DSDP Leg 40 Site 365.

Table 1 . Only those forms that could be readily referred to recent or described fossil species are recorded. For this reason the list does not represent the complete assemblage for each sample. A further restriction was imposed by the limited amount of core material available for preparation. The sample from Core 4 in particular gave an extremely poor yield which was sufficient only to verify the Tertiary age and show that the assemblage was similar to those from the deeper cores.

The lower age limit to the assemblages is given by the consistent and common occurrence in all samples of pollen of the family Compositae. The most abundant 
TABLE 1

Distribution of Tertiary Microplankton, Spores, and Pollen in Cores 4 to 7 From Site 365

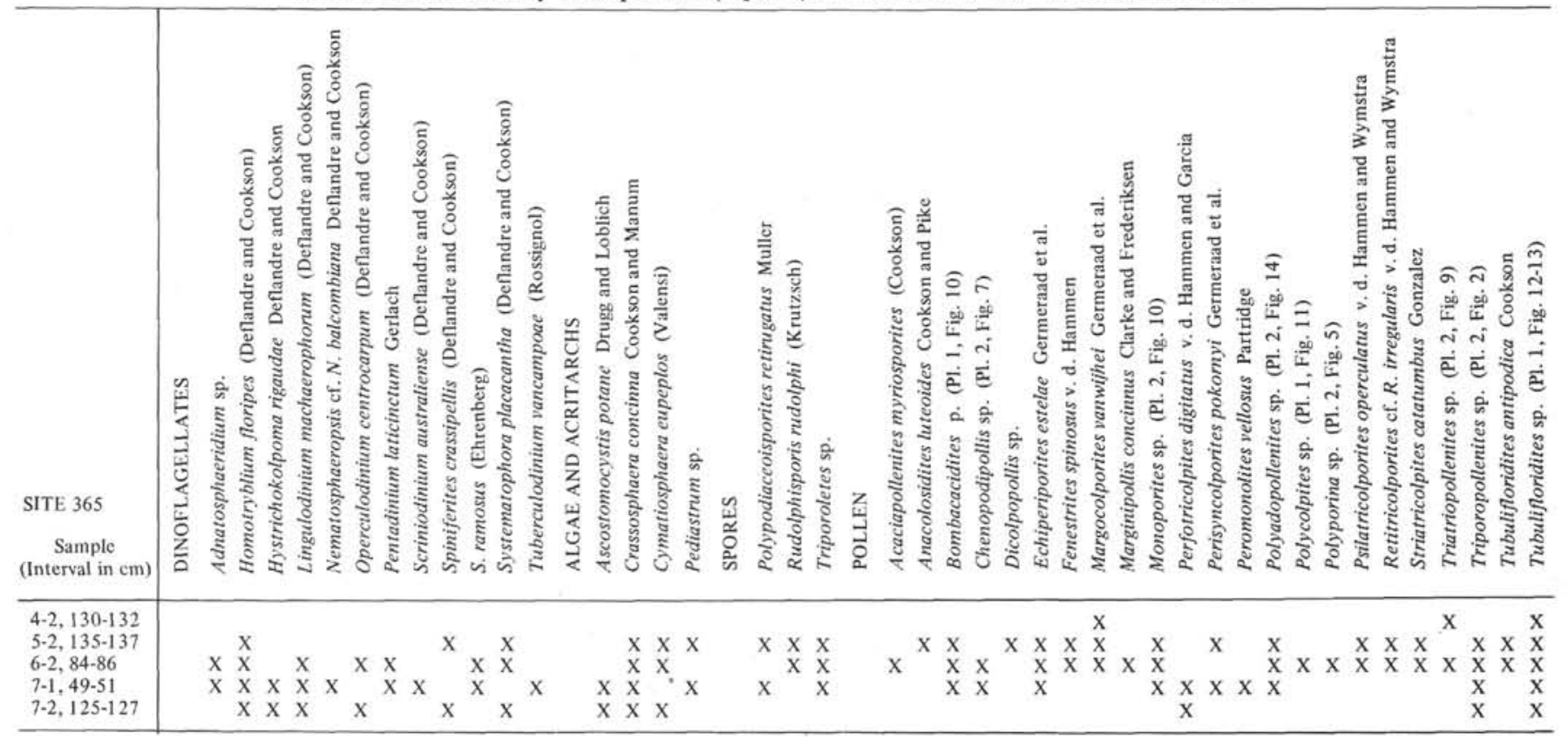

species is Tubulifloridites sp. which is similar to pollen from the recent genera Mutisia L. and Echinops L. The other representatives of this family, Tubulifloridites antipodica Cookson and Fenestrites spinosus van der Hammen are not as abundant. They belong, respectively, to the Tubuliflorae and Liguliflorae types of Germeraad et al. (1968), or the Ambrosia and Taraxacum types of Williams (1975) and other authors. Although this family has a fossil record extending questionably into the Oligocene (Leopold, 1969) it is first reliably recorded on all continents from early to middle Miocene (Germeraad et al., 1968; Stover and Partridge, 1973; Williams, 1975) and generally only consistently and abundantly in late Miocene or younger sediments.

Other pollen whose occurrences favor a young rather than older Tertiary age are: Acaciapollenites myriosporites (Cookson), Polyadopollenites sp. referable to the family Mimosaceae; Echiperiporites estelae Germeraad et al.; Chenopodipollis sp.; Marginipollis concinnus Clarke and Frederiksen; and Monoporites sp.

In conflict with the above Germeraad et al. (1968) records from Nigeria the extinction in the Oligocene of the pollen Margocolporites vanwijhei Germeraad et al. and Anacolosidites luteoides Cookson and Pike. It is the same with the dinoflagellates, for in the recent compilations of stratigraphic ranges by Drugg and Stover (1975) and Harker and Sarjeant (1975) the species Homotryblium floripes (Deflandre and Cookson), Pentadinium laticinctum Gerlach, Scriniodinium australiense (Deflandre and Cookson), and Systematophora placacantha (Deflandre and Cookson) are not recorded as occurring in sequences younger than middle to late Miocene. If these ranges are valid for the Angola Basin a youngest age limit of late Miocene is imposed on the assemblages. However, the recorded extinctions may only be an artifact of the amount of stratigraphic palynology published on the late Neogene.

Compositionally there is little difference between the samples. The samples from Cores 5 and 6 contain the most diverse assemblages, and both samples lack the acritarch Ascostomocystis potane Drugg and Loeblich which is common in the two samples from Core 7. Moreover, there is no recognizable age difference between the samples from Cores 4 to 7 .

A reworked Carboniferous to Permian monosaccate Parasaccites sp. was observed in Core 7 , but no reworked pollen characteristic of the Cretaceous assemblage found in Core 3 were observed in any of the samples.

\section{LATE CRETACEOUS ASSEMBLAGE}

The single sample available from Core 3 gave a limited yield of spore-pollen and dinoflagellates, along with abundant fine sapropelic material. A sample from Core $2(365-2-3,47-99 \mathrm{~cm})$ from the same sapropelic mudstone unit was also processed but did not yield any fossils. The assemblage from Core $3(365-3-3,45-47 \mathrm{~cm})$ is dominated by the pollen Hexaporotricolpites emelianovi with common Tricolpites sp. $\mathrm{H}$, and Ephedripites spp. The other components of the assemblage are uncommon to rare. The total assemblage is as follows:

Microplankton:

Cyclonephelium distinctum Deflandre and Cookson, 1955

Dinogymnium euclaensis Cookson and Eisenack, 1970

Pterospermopsis microptera Deflandre and Cookson, 1955

Spore-Pollen:

Hexaporotricolpites emelianovi Boltenhagen, 1967

Tricolpites sp. H, Morgan, this volume (pl. 1, fig. 1) 
Tricolporites sp. (pl. 1, fig. 6, 7)

Steevesipollenites spp.

Ephedripites spp.

Gabonisporis vigourouxii Boltenhagen, 1967

Although this is a limited assemblage, it nevertheless is distinctly Late Cretaceous in age. A more definitive age is Turonian to lower Senonian based on the abundance of $\mathrm{H}$. emelianovi (Jardine et al., 1975), the presence of Gabonisporis vigourouxii (Herngreen, 1975) and comparison with Site 364 (Morgan, this volume).

The similarity in species composition and style of preservation between Core 3 and the Cretaceous sediments at Site 364 strongly suggest that the sapropelic mudstone unit in the Site 365 sequence represents Cretaceous sediments and not the wholesale reworking of the assemblage into the Tertiary sequence. No anomalous species were observed in Core 3 to support the possible interpretation that the assemblage was recycled. The reworking interpretation also suffers because of the lack of recycled fossils of this age in the underlying Cores 4 to 7 . Consequently the slumping or faulting of the sapropelic mudstones into the submarine canyon is the preferred interpretation for their origin.

\section{SYSTEMATIC NOTES}

The object of the short systematic section is to discuss recent affinities, stratigraphic ranges, and sources of some of the less well known pollen. Most of the pollen not mentioned can be found in Germeraad et al. (1968), while the sources of the dinoflagellate nomenclature can be found by referring to Lentin and Williams (1973).

For consistency all spore-pollen species identified in Table 1 are given names of fossil form genera and species. Even though many can be referred to living species, as will be discussed, they are still retained under a form-fossil nomenclature as this procedure avoids the likelihood of the incorrect assignment of the dispersed fossils.

Those palynological slides containing the specimens illustrated are deposited in the N.S.W. Department of Mines' Mining Museum Micropaleontological Collection where they have been assigned the catalog numbers MMMC 2015 to 2029. A master slide for coordination of the specimens has been assigned the catalog number MMMC 2030.

\section{SPORES}

\section{Genus RUDOLPHISPORIS Krutzsch, 1963}

Rudolphisporis rudolphi (Krutzsch)

Rudolphisporis rudolphi (Krutzsch) Krutzsch, 1963 (p. 56, pl. 9, fig. 1-7)

Reticulatisporites echinatus Martin, 1973, p. 10, fig. 39, 40 Reticulatisporites mangapipiensis Mildenhall, 1975, p. 668, fig. 1-7

Remarks: A rare species in the preparations having an Oligocene to Miocene range in Europe but as yet only recorded from the Pliocene and Pleistocene in Australia and New Zealand.

Genus TRIPOROLETES Mtchedlishvili, 1960

\section{Triporoletes sp.}

Remarks: Spores conforming with those from the living bryophte genus Riccia are placed under this form genus. Stratigraphic range observed by author is late Eocene to Recent.

\section{POLLEN}

\section{Genus ACACIAPOLLENITES Mildenhall, 1972}

Acaciapollenites myriosporites (Cookson) Mildenhall, 1972 (Plate 2, Figure 13)

Remarks: The single specimen recorded of this smaller polyad is consistent with the variation accepted in this species in Australia and
New Zealand (Mildenhall, 1972). The grain has the vestigial quadrangular furrows described by Mildenhall and still has preserved most of the granulate sexine layer which is normally stripped off during preparation. The earliest occurrence of this pollen in Australasia is from the early Miocene (Stover and Partridge, 1973).

\section{Genus CHENOPODIPOLLIS Krutzsch, 1966}

\section{Chenopodipollis sp. \\ (Plate 2, Figure 7)}

Remarks: Periporate pollen of referable to the family Chenopodiaceae have a consistent fossil record back as far as the Oligocene (Krutzsch, 1966; Stover and Partridge, 1973, fig. 2).

\section{Genus DICOLPOPOLLIS Pflanzl, 1956}

\section{Dicolpopollis sp.}

Remarks: A single specimen of this form was observed and is identical to the pollen of the sago palm Metroxylon salomonense illustrated by Sowunmi (1972, p. 9, fig. 7, 8).

Genus ECHIPERIPORITES van der Hammen and Wymstra, 1964

Echiperiporites estelae Germeraad, Hopping, and Muller, 1968 (Plate 2, Figures II and 12)

Remarks: Pollen of the family Malvaceae are well represented in the assemblages though only a few specimens agree exactly with the description of Echiperiporites estelae. The abundance and diversity of this group in the assemblages favors a younger Neogene age (see Germeraad et al., 1968, p. 316).

Genus MARGINIPOLLIS Clarke and Frederiksen, 1968

\section{Marginipollis concinnus Clarke and Frederiksen, 1968} (Plate 2, Figure 1)

Remarks: Pollen comparable with the mangrove genus Barring. tonia J.R. \& G. Forst. are described under this name by Clarke and Frederiksen (1968) from the late Tertiary of Nigeria.

Genus MONOPORITES Cookson ex van der Hammen. 1954

\section{Monoporites sp. \\ (Plate 2, Figure 10)}

Remarks: Pollen referable to the noncultivated grasses (family Gramineae) is common in the more productive samples. The rise in abundance of grass pollen is a feature characteristic of the N ogene pollen record (Germeraad et al., 1968).

\section{Genus POLYADOPOLLENITES Pflug and Thomson in Thomson and Pflug, 1953}

Polyadopollenites sp.
(Plate 2, Figure 14)

Remarks: This species is compared with the species of Acacia Willd. illustrated by Maley (1972, pl. 3, fig. 7 and pl. 4, fig. 20, 21) from the recent pollen spectra of Lake Chad, and by Sowumni (1973, p. 5, fig. 10-13).

\section{Genus POLYCOLPITES Couper, 1953}

\author{
Polycolpites sp. \\ (Plate 1, Figure 11)
}

Remarks: A conspicuous species in the sample from Core 6, similar to Symphonia globulifera L. illustrated by Sowunmi (1973, p. 4, fig. 8-12).

\section{Genus POLYPORINA Naumova ex Potonié, 1960}

\section{Polyporina sp.}

(Plate 2, Figure 5)

Remarks: A number of periporate pollen types were observed in the assemblages but with the exception of Chenopodipollis sp. they could not be referred to fossil or recent species. The specimen illustrated is characterized by a coarsely reticulate sexine with a distinct, tall columellae layer. The pores occur in the luminae of the 
reticulum. In southeastern Australia morphologically similar pollen has not been recorded by the author in sediments older than Pliocene.

Genus RETITRICOLPORITES van der Hammen ex van der Hammen and Wymstra, 1964

\section{Retitricolporites sp. cf. R. irregularis van der Hammen and Wymstra, 1964}

Results: Specimens compared with $R$. irregularis although of similar size are characterized by a much coarser and more regular reticulum.

Genus TRIATRIOPOLLENITES Pflug in Thomson and Pflug, 1953

\section{Triatriopollenites sp.}

(Plate 2, Figure 9)

Remarks: Pollen from genera belonging to the families Myricaceae and Casuarinaceae and to a lesser extent the family Betulaceae are virtually indistinguishable between themselves and from the form illustrated. The stratigraphic record of this particular pollen type extends back at least into the early Paleocene.

Genus TRIPOROPOLLENITES Pflug and Thomson in Thomson and Pflug, 1953

\section{Triporopollenites sp.}

(Plate 2, Figure 2)

Remarks: This is a common species in the Tertiary samples and is closely comparable to pollen from Triplochiton scleroxylon $\mathrm{K}$. Schlum illustrated by Sowunmi (1973, pl. 9, fig. 6-8).

\section{Genus TUBULIFLORIDITES Cookson ex Potonié, 1960}

\section{Tubulifloridites antipodica Cookson, 1947}

(Plate 2, Figures 3 and 4)

Remarks: This is not a very common pollen type in the Tertiary samples but its presence gives an important lower age limit to the section. The specimens included in this species differ only in having less pronounced spines from the probably junior synomym Echitricolporites spinosus van der Hammen which has been used by Germeraad et al. (1968) as a pantropical zone marker. Although this type has been recorded from the early Miocene it is usually very rare until much later in the Miocene.

Tubulifloridites sp.

(Plate 1, Figures 12, 13)

Remarks: This Compositae pollen is the commonest individual pollen type in Cores 4 to 7 . It is very similar to pollen from the plant genera Mutisia L. and Echinops L. The author is unaware whether it has been previously recorded from pre-Pleistocene sediments.

\section{ACKNOWLEDGMENTS}

The samples were supplied by R.P. Morgan of the New South Wales Department of Mines, when it was recognized, upon preparation, that they were substantially younger than the stratigraphic section in Site 364 with which they had been initially correlated.

The author also wishes to thank Esso Australia Ltd. for permission to publish the paper.

\section{REFERENCES}

Bolli, H.M., Ryan, W.B.F., et al., 1975. Basins and margins of the eastern South Atlantic: Geotimes, v. 20, p. 22-24.

Clarke, R.T. and Frederiksen, N.O., 1968. Some new sporomorphs from the Upper Tertiary of Nigeria: Grana, v. 8, p. $210-223$.

Drugg, W.S. and Stover, L.E., 1975. Stratigraphic range charts-selected Cenozoic dinoflagellates: Am. Assoc. Stratigr. Palynol., Contrib. Ser., no. 4, p. 73-76.

Germeraad, J.H., Hopping, C.A., and Muller, J., 1968. Palynology of Tertiary sediments from Tropical areas: Rev. Palaeobot. Palynol., v. 6, p. 189-348.

Harker, S.D. and Sarjeant, W.A.S., 1975. The stratigraphic distribution of organic-walled dinoflagellate cysts in the Cretaceous and Tertiary: Rev. Palaeobot. Palynol., v. 20, p. 217-315.

Herngreen, G.F.W., 1975. An upper Senonian pollen assemblage of Borehole 3-P1A-10-AL State of Alagolas, Brazil: Pollen et Spores, v. 17, p. 93-140.

Jardine, S., Doerenkamp, A., and Legoux, O., 1975. Le genre Hexaporotricolpites Boltenhagen 1967 morphologie, systematique, stratigraphie et extension geographique: Quart. Coll. Afr. Micropal., p. 175-188.

Krutzsch, W., 1963. Atlas der mittel-und jungtertiären dispersen Sporen-und Pollen-sowie der Mikroplanktonformen des nördlichen Mitteleuropas: Lief. II. VEB Deutscher Verlagder Wissenschaften, Jena, p. 1-141. 1966. Zur Kenntnis der präquartäre periporaten Pollenformen: Geologie, v. 15, p. 16-72.

Lentin, J.K. and Williams, G.L., 1973. Fossil dinoflagellates: Index to genera and species: Geol. Sur. Canada, Paper 7342, p. $1-176$

Leopold, E. B., 1969. Late Cenozoic palynology. In Tschudy, R.H. and Scott, R.A. (Eds.), Aspects of palynology: New York (Wiley-Interscience), p. 377-438.

Maley, J., 1972. La sédimentation pollinique actuelle dans la zone du lac Tchad (Afrique Centrale): Pollen et Spores, v. 14, p. $263-307$

Martin, H.A., 1973. The palynology of some Tertiary Pleistocene deposits, Lachlan River Valley, New South Wales, Australian J. Bot., Suppl. Ser., No. 6, p. 1-57.

Mildenhall, D.C., 1972. Fossil pollen of Acacia type from New Zealand: New Zealand J. Bot., v. 10, p. 485-494. 1975. New fossil spore from the Pakihikura Pumice (Okehuan; Quaternary), Rangitikei Valley, New Zealand: New Zealand J. Geol. Geophys., v. 18, p. 667-673.

Sowunmi, M.A., 1972. Pollen morphology of the Palmae and its bearing on taxonomy; Rev. Palaeobot. Palynol., v. 13, p. $1-80$.

1973. Pollen grains of Nigerian plants: Grana, v. 13 , p. $145-186$.

Stover, L.E. and Partridge, A.D., 1973. Tertiary and late Cretaceous spores and pollen from the Gippsland Basin, southeastern Australia: Roy. Soc. Victoria Proc., v. 85, p. $237-286$.

Williams, G.L., 1975. Dinoflagellate and spore stratigraphy of the Mesozoic-Cenozoic, offshore Eastern Canada. In Offshore geology of Eastern Canada: Geol. Surv. Can., Paper 74-30, v. 2, p. 107-161. 



\section{PLATE 1}

All magnifications $\times 800$ unless stated otherwise.

Late Cretaceous assemblage (Figures 1-8. All from Sample 365-3-3, $45-47 \mathrm{~cm})$.

Late Tertiary assemblage (Figures 9-13).

Figure 1 Tricolpites sp. H., Morgan. Polar and equatorial foci levels. MMMC 2015: 23.5, 100.9.

Figures 2, 3 Hexaporotricolpites emelianovi Boltenhagen, 1967.

2a-c. Proximal and sectional foci, MMMC 2016; 08.7, 94.3.

3a-d. Proximal, sectional and distal foci; MMMC 2018: 03.9, 106.2.

Figure $4 \quad$ Steevesipollenites sp., MMMC 2017: 21.1, 88.8.

Figure $5 \quad$ Ephedripites sp., MMMC 2017: 18.5, 106.5.

Figures 6,7 Tricolporites sp. 6, proximal foci, MMMC 2019:20.1, 93.5.

7a-c Proximal and sectional foci, MMMC 2017, 19.2, 83.1.

Figure 8 Dinogymnium euclaensis Cookson and Eisenack, 1970. Dorsal and sectional foci, MMMC

2015: $10.1,110.5$.

Figure 9 Polypodiaceoisporites retirugatus Muller, 1968. Distal and equatorial foci, $\times 500$, MMMC 2020:

$22.3,115.4$. Sample $365-5-2,135-137 \mathrm{~cm}$.

Figure $10 \quad$ Bombacacidites sp. Polar equatorial foci, MMMC 2021: 19.2, 102.7. Sample 365-6-2, 84-86 cm.

Figure 11 Polycolpites sp. Polar and equatorial foci, MMMC 2022: 04.3, 105.6. Sample 365-6-2, 84-86 $\mathrm{cm}$.

Figures 12, 13 Tubulifloridites $\mathrm{sp}$.

$12 \mathrm{a}, \mathrm{b}$. Sectional foci of equatorial view, MMC 2023: 12.4, 105.6. Sample 365-5-2, 135-137 cm.

$13 \mathrm{a}, \mathrm{b}$. Proximal and sectional foci of equatorial view, MMMC 2022: 07.5, 116.0. Sample 365-6-2, $84-86 \mathrm{~cm}$. 
PLATE 1

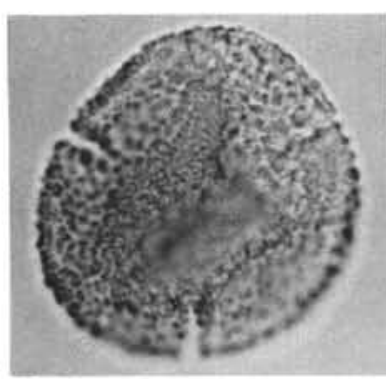

$1 a$
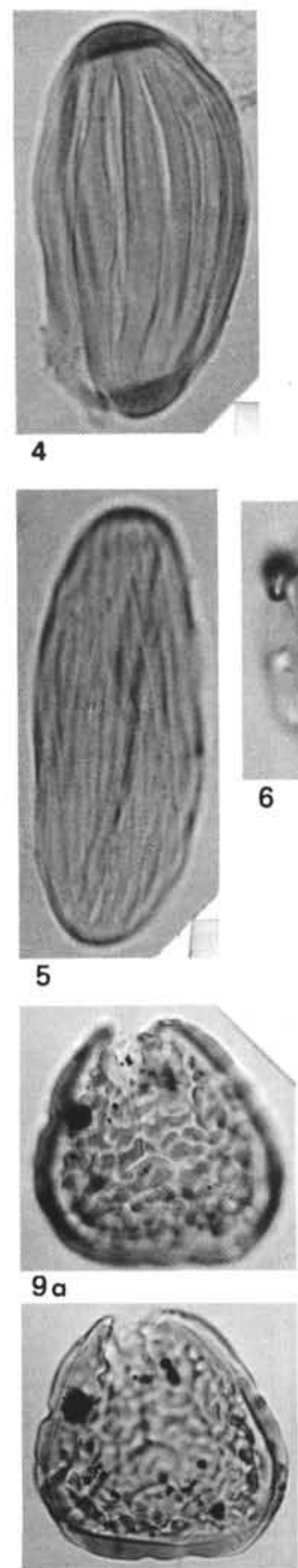

$9 b$

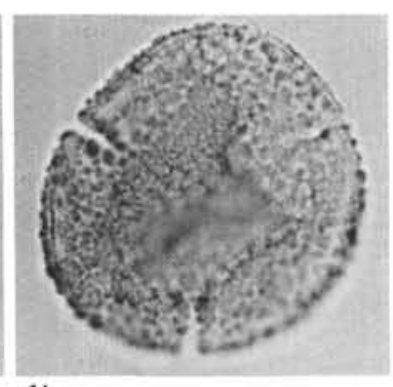

$1 b$

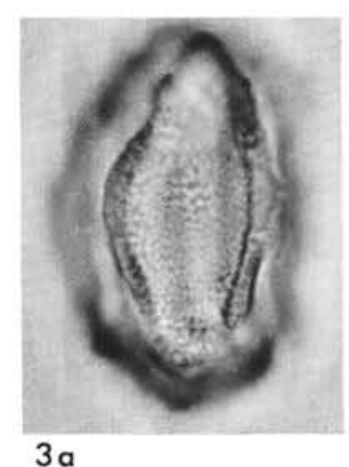

$3 a$

$3 b$

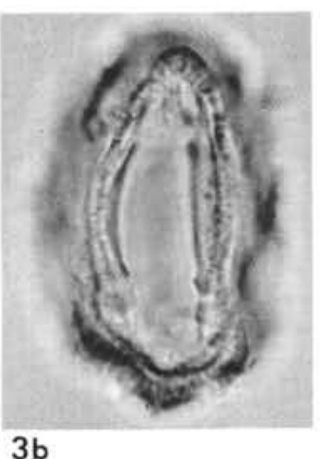

$3 c$
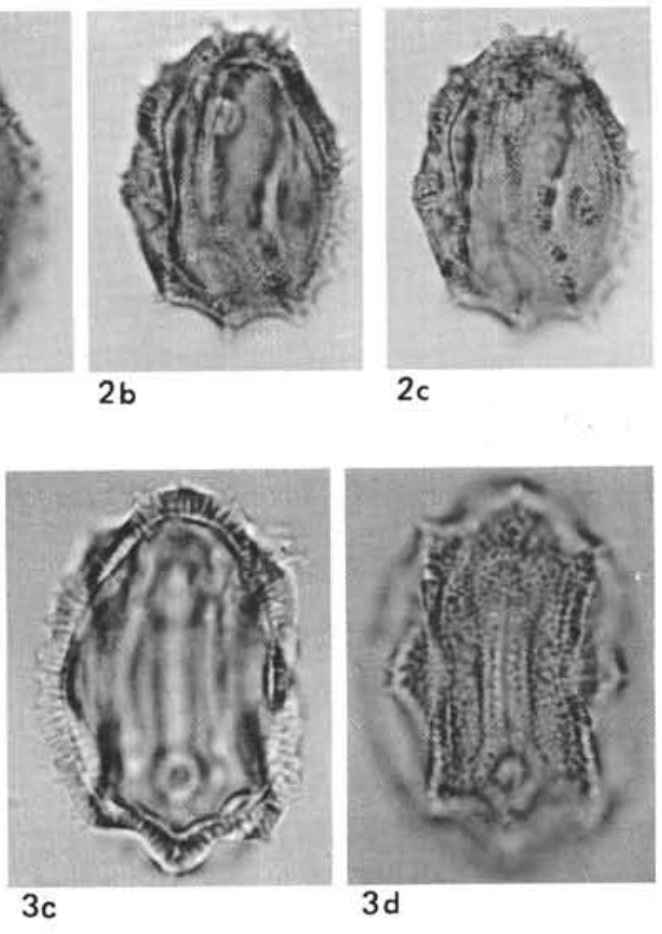

$2 b$ 2c
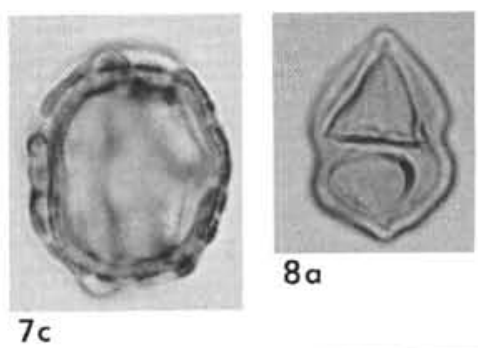

$8 a$

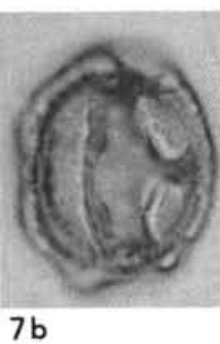

$10 \mathrm{~b}$

$12 a$

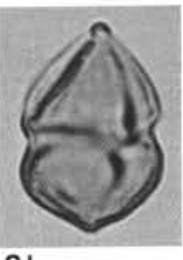

$8 b$

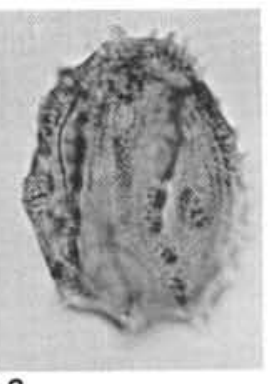

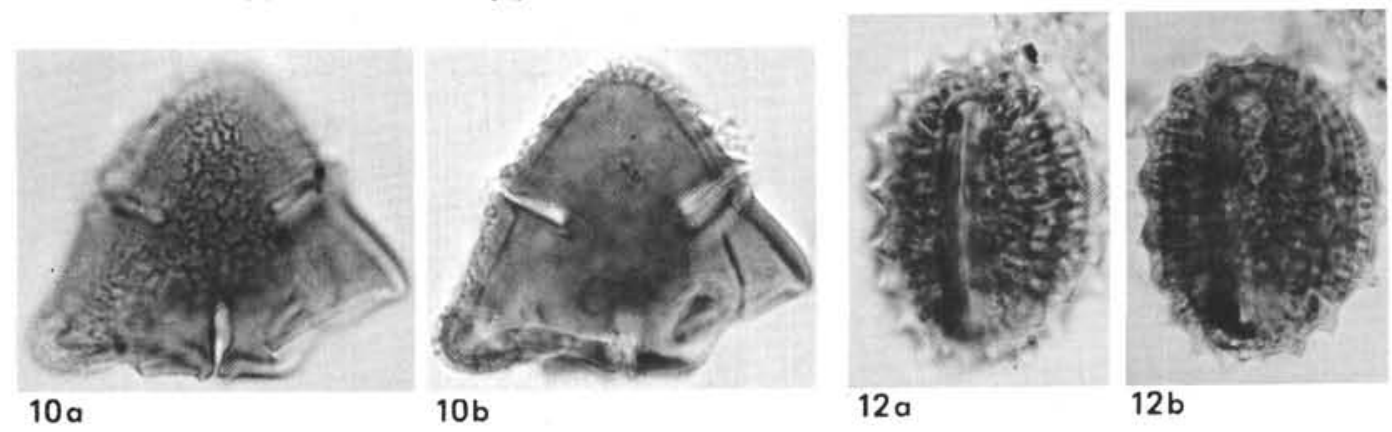

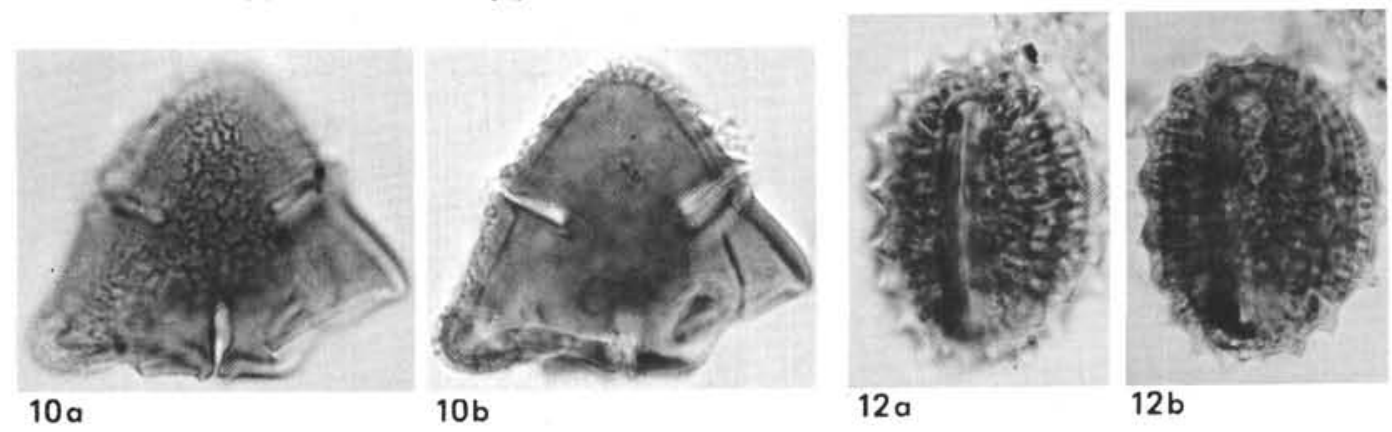

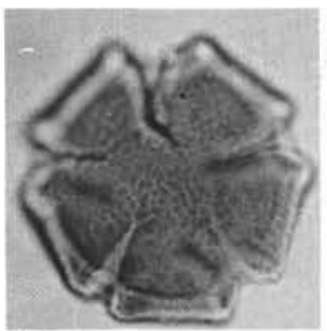

11a

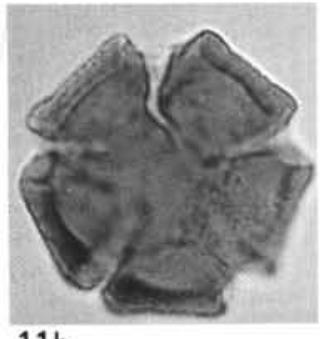

$11 \mathrm{~b}$

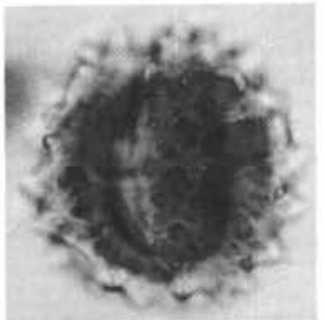

$13 a$

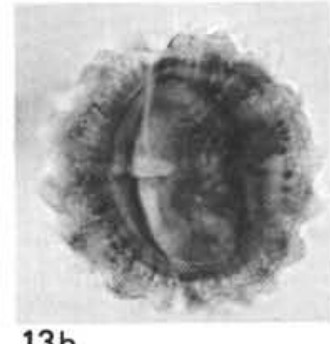

$13 b$ 


\section{PLATE 2}

Late Tertiary assemblage

Figure 1 Marginipollis concinnus Clarke and Frederiksen, 1968. Sectional foci of equatorial view, MMMC 2024: 08.2, 91.3. Sample 365-6-2, $84-86 \mathrm{~cm}$.

Figure 2 Triporopollenites sp. Sectional foci, polar view, MMMC 2025: 05.1, 87.9. Sample 365-5-2, 135-137 $\mathrm{cm}$.

Figures 3,4 Tubulifloridites antipodica Cookson, 1947.

3a-d. Foci levels in equatorial view, MMMC 2026: 10.3, 113.5.

4a, b. Polar and equatorial foci, MMMC 2024: 07.9, 118.0. Sample 365-6-2, 84-86 cm.

Figure 5 Polyporina sp. Foci on reticulum, at pores in nexine and equatorial section, MMMC 2021: 04.3, 105.6. Sample 365-6-2, $84-86 \mathrm{~cm}$.

Figure 6 Margocolporites vanwijhei Germeraad, Hopping and Muller, 1968. Polar surface and equatorial foci, $\times 500$, MMMC 2021: 08.2, 113.9. Sample $365-6-2,84-86 \mathrm{~cm}$.

Figure 7 Chenopodipollis sp. Polar surface and equatorial foci, MMMC 2021: 22.3, 109.7. Sample 365-6-2, $84-86 \mathrm{~cm}$.

Figure $8 \quad$ Anacolosidites luteoides Cookson and Pike, 1954. Polar surface and equatorial foci, MMMC 2027: 18.7, 108.3. Sample 365-5-2, 135-137.

Figure 9 Triatriopollenites sp. Equatorial section $\times 500$, MMMC 2022: 09.5, 103.5. Sample 365-6-2, 84-86 $\mathrm{cm}$.

Figure $10 \quad$ Monoporites sp., MMMC 2028: 08.9, 99.6. Sample $365-5-2,135-137 \mathrm{~cm}$.

Figures 11, 12 Echiperiporites estelae Germeraad, Hopping and Muller, 1968.

$11 \mathrm{a}, \mathrm{b}$. Two foci of folded grain, $\times 500$. MMMC 2029: 06.0, 115.1. Sample 365-7-1, 49-57 cm.

12. Equatorial focus $\times 500$, MMMC 2024: 10.3 , 95.3. Sample $365-6-2,84-86 \mathrm{~cm}$.

Figure 13 Acaciapollenites myriosporites (Cookson) Mildenhall, 1972. Polar and equatorial foci, MMMC 2021: 17.3, 104.2. Sample 365-6-2, 84-86 $\mathrm{cm}$.

Figure 14 Polyadopollenites sp. Folded, inclined specimen, $\times 500$, MMMC 2021: 11.8, 108.3. Sample 365-6-2, $84-86 \mathrm{~cm}$.

Figure 15 Parasaccites sp. Recycled Permian specimen, $\times 320$, MMMC 2029: 07.8, 110.9. Sample 365-7-1, $49-57 \mathrm{~cm}$. 
PLATE 2
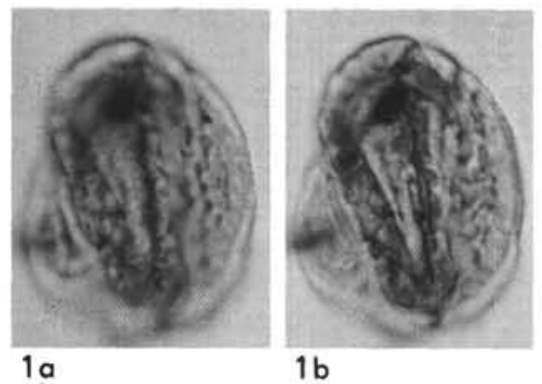

1b

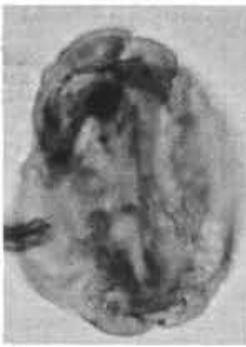

$1 c$

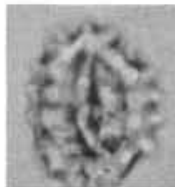

$3 a$

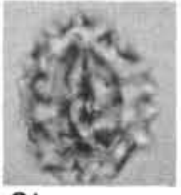

$3 b$

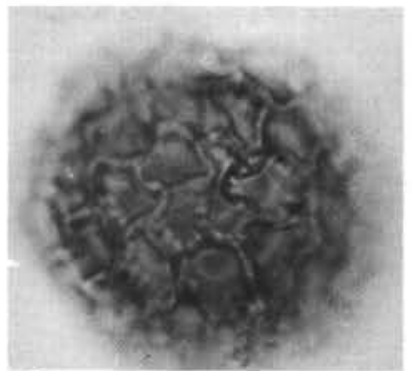

$5 a$

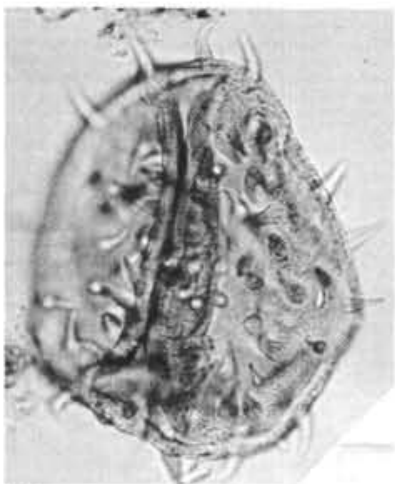

$11 \mathrm{a}$

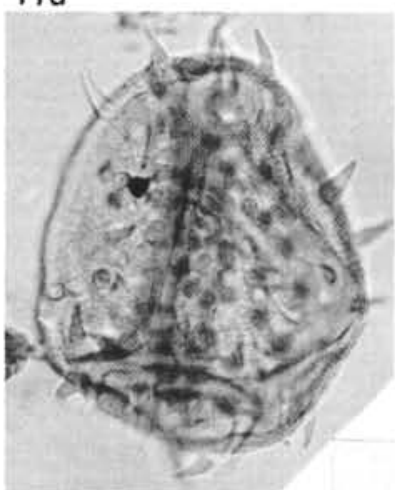

$11 b$

$3 c$
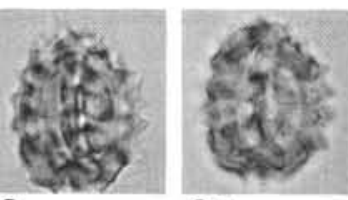

$3 d$

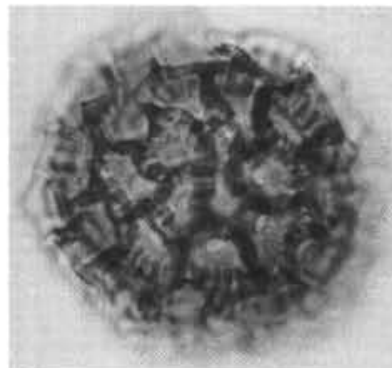

$5 b$

$5 c$
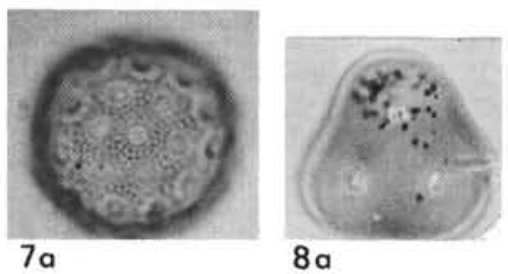

$8 a$
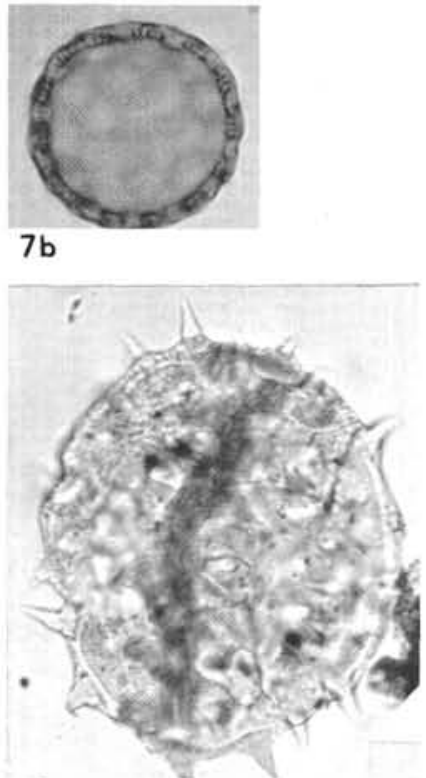
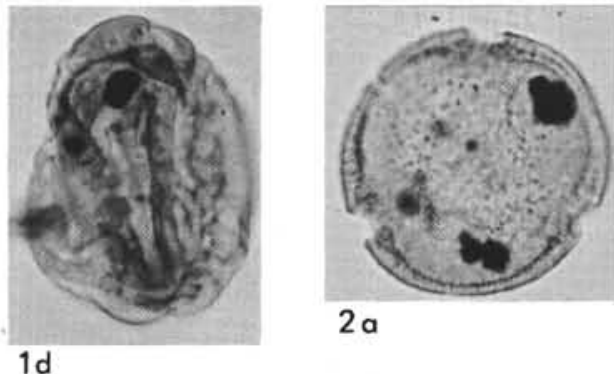

$2 a$
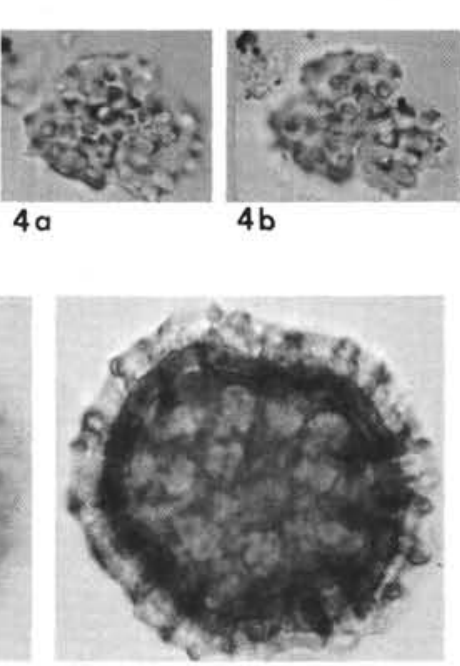

12
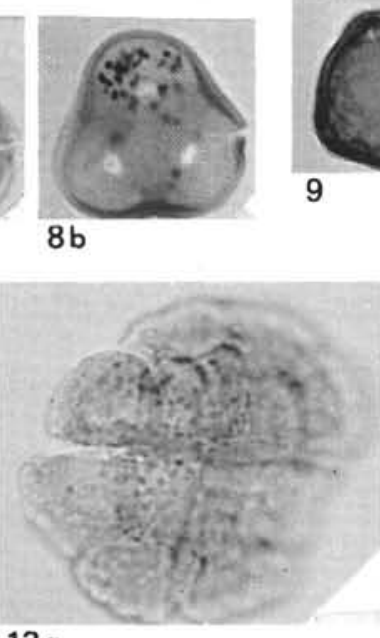

$13 a$

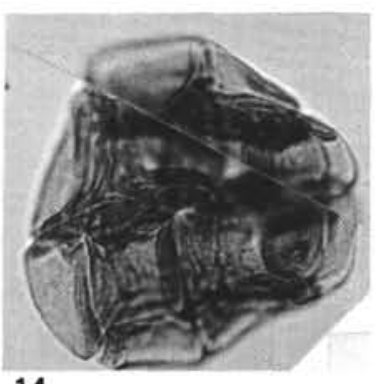

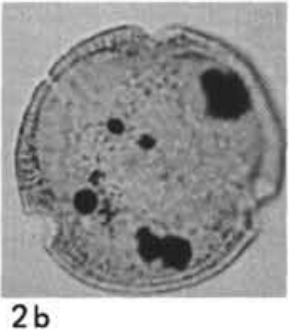

$2 b$

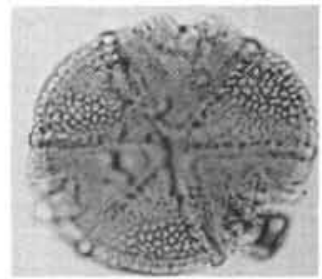

$6 a$

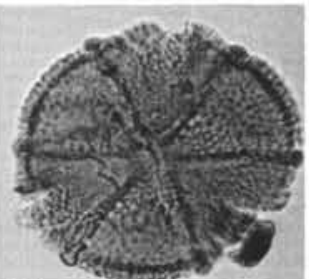

$6 b$
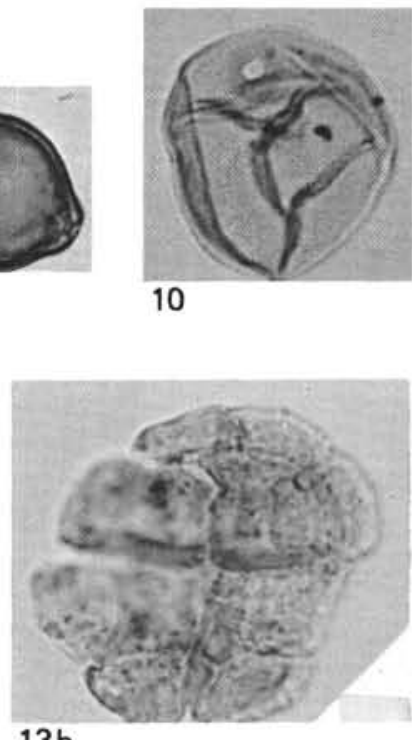

$13 b$

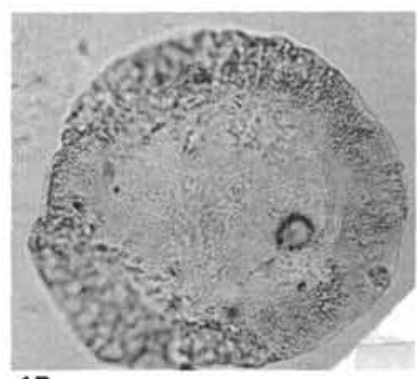

